\title{
KELIMPAHAN LARVA IKAN SAAT PASANG DAN SURUT DI PERAIRAN SEKTAR LOKASI WISATA BAHARI DUKUH MOROSARI DESA BEDONO, KABUPATEN DEMAK
}

\author{
Fish Larvae Abundance at High Tide and Low Tide in Around Waters Marine Tourism Morosari of Bedono \\ Village, Demak.
}

\section{Dicky Setya Rachmawan, Norma Afiati*), Niniek Widyorini}

Program Studi Manajemen Sumberdaya Perairan, Departemen Sumberdaya Akuatik

Fakultas Perikanan dan Ilmu Kelautan Universitas Diponegoro

Jl. Prof. Soedarto, SH, Tembalang, Semarang, Jawa Tengah - 50275, Telp/Fax. +6224 7474698

Email : dickysetya99@gmail.com

\begin{abstract}
ABSTRAK
Perairan Morosari merupakan kawasan pesisir yang memiliki dinamika tinggi akibat dari adanya objek wisata bahari, dimana akan berpengaruh pada struktur komunitas sumberdaya perikanan, salah satu diantaranya adalah larva ikan yang ada diperairan tersebut. Larva ikan merupakan fase massa kritis dimulai bagi ikan, dimana pembentukan organ tubuh belum terbentuk secara sempurna. Penelitian ini bertujuan untuk mengetahui jenis dan kelimpahan larva ikan berdasarkan pasang surut yang terdapat di perairan sekitar lokasi wisata bahari Dukuh Morosari Desa Bedono, Kabupaten Demak. Penelitian dilaksanakan pada bulan Juli 2017. Metode penelitian yang digunakan adalah survei dengan penentuan titik sampling secara purposive yang dilakukan di 6 stasiun baik pada saat pasang dan surut. Hasil yang diperoleh menunjukkan bahwa jumlah larva ikan yang tertangkap sebanyak 1156 ind $/ 600 \mathrm{~m}^{3}$ terdiri dari 8 famili yakni: Ambassidae $\left(551 \mathrm{ind} / 600 \mathrm{~m}^{3}\right)$, Belonidae $\left(33 \mathrm{ind} / 600 \mathrm{~m}^{3}\right)$, Engraulidae $(118$ ind $\left./ 600 \mathrm{~m}^{3}\right)$, Gobiidae $\left(8 \mathrm{ind} / 600 \mathrm{~m}^{3}\right)$, Lutjanidae $\left(7 \mathrm{ind} / 600 \mathrm{~m}^{3}\right)$, Mugilidae $\left(130 \mathrm{ind} / 600 \mathrm{~m}^{3}\right)$, Nemipteridae (206 ind $\left./ 600 \mathrm{~m}^{3}\right)$, Oryziatidae $\left(103 \mathrm{ind} / 600 \mathrm{~m}^{3}\right)$. Larva famili Ambassidae merupakan larva yang paling banyak tertangkap, sedangkan larva yang tertangkap dengan jumlah paling sedikit ialah famili Lutjanidae. Hasil uji Independent-Sample T test ialah tidak terdapat perbedaan yang signifikan antara kelimpahan larva ikan saat pasang dan surut pada setiap stasiun maupun setiap pengulangan. Jumlah larva ikan pada saat pasang $613 \mathrm{ind} / 600 \mathrm{~m}^{3} \mathrm{dan}$ pada saat surut 543 ind $/ 600 \mathrm{~m}^{3}$.
\end{abstract}

Kata kunci: Larva ikan; Kelimpahan; Pasang Surut; Perairan Dukuh Morosari Desa Bedono, Kabupaten Demak.

\section{ABSTRACT}

Morosari waters are coastal areas that have high dynamics due to the existence of marine tourism object, which will affect the structure of the fishery resources community, one of which is the fish larvae that existed in these waters. Fish larvae is a critical mass phase begun for fish, where the formation of organs has not been fully formed. This study aims to determine the type and fish larvae abundance based on High Tide and Low Tide at Around Waters Marine Tourism Morosari of Bedono Village, Demak. The research was conducted in July 2017. The research method used a survey with purposive sampling conducted at 6 stations both at High Tide and Low Tide. The results showed that the number of fish larvae caught were 1156 ind $/ 600 \mathrm{~m}^{3}$ consisting of 8 families: Ambassidae $\left(551 \mathrm{ind} / 600 \mathrm{~m}^{3}\right)$, Belonidae $\left(33 \mathrm{ind} / 600 \mathrm{~m}^{3}\right)$, Engraulidae $\left(118 \mathrm{ind} / 600 \mathrm{~m}^{3}\right)$, Gobiidae $\left(8 \mathrm{ind} / 600 \mathrm{~m}^{3}\right)$, Lutjanidae $\left(7 \mathrm{ind} / 600 \mathrm{~m}^{3}\right)$, Mugilidae $\left(130 \mathrm{ind} / 600 \mathrm{~m}^{3}\right)$, Nemipteridae $\left(206 \mathrm{ind} / 600 \mathrm{~m}^{3}\right)$, Oryziatidae (103 ind $\left./ 600 \mathrm{~m}^{3}\right)$. The family larvae of Ambassidae are most caught larvae, while the larvae caught with the least amount are the Lutjanidae family. The result of the Independent-Sample $T$ test is no significant different between the abundance of fish larvae during tidal and low tide at each station and every repetition. Number of fish larvae at high tide 613 ind $/ 600 \mathrm{~m}^{3}$ and at low tide 543 ind $/ 600 \mathrm{~m}^{3}$.

Keywords: Fish larvae; Abundance; high tide and low tide; Marine Tourism Morosari of Bedono Village, Demak

*) Penulis penanggungjawab

\section{PENDAHULUAN}

Wisata bahari merupakan bentuk wisata yang menggunakan atau memanfaatkan potensi lingkungan pantai dan laut sebagai daya tarik utama. Potensi wisata bahari di Indonesia sangat beragam dan memiliki nilai keindahan yang tidak kalah menarik dibandingkan dengan negara-negara lain, baik yang sudah berkembang

\footnotetext{
${ }^{\oplus}$ Copyright by Management of Aquatic Resources (MAQUARES)
} 
maupun yang belum berkembang. Wisata alam yang berupa pantai, mangrove, wisata air dan sebagainya merupakan beberapa contoh dari potensi wisata bahari yang ada di Indonesia, tak terkecuali di daerah Jawa Tengah yang saat ini mulai dikembangkan (Djou, 2013).

Desa Bedono secara geografis merupakan salah satu desa yang terdapat di Kecamatan Sayung, Kabupaten Demak, Jawa Tengah dengan luas total wilayah yaitu 551.673 Ha. dan terdiri atas 7 dukuh yaitu: Tonosari, Morosari, Pandansari, Tambaksari, Rejosari (Senik), Mondoliko dan Bedono. Letaknya yang berdekatan dengan Kota Semarang menjadikan wilayah Kabupaten Demak sebagai destinasi wisata warga Kota Semarang dan sekitarnya. Menurut Rohman (2016), wisata yang ada di perairan Morosari diantaranya adalah hutan mangrove, wisata religi dan wisata pantai yang menjadi daya tarik wisata bagi pengunjung dari berbagai daerah.

Larva ikan merupakan tahap awal dari pertumbuhan ikan. Seperti hewan-hewan laut lainnya, larva juga dipengaruhi oleh banyak faktor lingkungan bagi kelulushidupannya dan menentukan kelangsungan hidup dari satu spesies ikan maupun populasi ikan tersebut. Begitu banyak larva ikan yang dihasilkan oleh induknya namun tidak semuanya hidup. Sebagian kecil saja yang mampu bertahan dan hidup hingga dewasa hal ini karena faktor lingkungan laut yang sangat bervariasi.

Keberadaan ichtyoplankton pada suatu perairan dapat digunakan untuk mengetahui tingkat produktivitas suatu perairan (Romimohtarto dan Juwana, 2004), karena kelimpahan ichtyoplankton pada suatu perairan dapat menggambarkan jumlah ketersediaan pakan, maupun kapasitas lingkungan/daya dukung lingkungan yang dapat menunjang kehidupan biota. Dengan demikian perubahan kelimpahan biota ichtyoplankton dapat digunakan untuk mengetahui perubahan yang terjadi pada suatu wilayah perairan.

Penelitian di bidang kehidupan awal ikan terutama tentang ichtyoplankton atau larva ikan di Indonesia masih cukup jarang sehingga belum memberikan sumbangan yang signifikan dalam manajemen perikanan yang saat ini berbasis pengelolaan yang berkelanjutan (sustainable fisheries). Dengan melakukan survei ichtyoplankton dalam jangka waktu yang panjang maka kita akan dapat mengetahui informasi mengenai lokasi pemijahan dan waktu pemijahan.

Tujuan dari penelitian ini adalah sebagai berikut:

1. Mengetahui jenis larva ikan yang terdapat di perairan sekitar lokasi Wisata Bahari Dukuh Morosari Desa Bedono, Kabupaten Demak.

2. Mengetahui kelimpahan larva ikan berdasarkan pasang surut yang terdapat di perairan sekitar lokasi Wisata Bahari Dukuh Morosari Desa Bedono, Kabupaten Demak.

\section{MATERI DAN METODE} Materi

Alat yang digunakan untuk sampling lapangan adalah Seine Net dengan mesh size $1 \mathrm{~mm}$ untuk menyaring larva ikan, botol sampel untuk wadah sampel; kertas label; kamera digital dan alat tulis. Alat yang digunakan pada saat pengukuran kualitas air yaitu, GPS untuk menentukan titik lokasi pengambilan sampel; termometer air raksa digunakan untuk mengukur suhu air dan suhu udara; current meter digunakan untuk mengukur kecepatan arus; refraktometer untuk mengukur salinitas; Secchi disk untuk pengukuran kecerahan dan kedalaman perairan; $\mathrm{pH}$ universal untuk mengukur $\mathrm{pH}$. Alat yang digunakan dalam analisis di laboratorium yaitu buku identifikasi larva ikan; penggaris; microskop stereo digunakan untuk mengamati larva ikan; cawan Petri digunakan untuk mencacah dan identifikasi larva ikan; alat bedah untuk membantu memindahkan sampel larva dalam proses identifikasi; dan form identifikasi larva dan alat tulis untuk mencatat hasil identifikasi.

Bahan yang digunakan dalam penelitian ini adalah larva ikan yang tertangkap di perairan sekitar lokasi wisata bahari Dukuh Morosari Kabupaten Demak; formalin 4\% untuk mengawetkan larva ikan dan data pasang surut.

\section{Metode}

Metode yang digunakan dalam penelitian ini adalah metode survei. Menurut Nazir (1999), metode survei adalah penyelidikan yang diadakan untuk memperoleh fakta dari gejala yang ada dan mencari keterangan secara faktual. Penelitian ini dilakukan untuk memperoleh data tentang kelimpahan larva ikan berdasarkan pasang surut serta data penunjangnya. Metode yang digunakan dalam pengambilan sampel adalah metode purposive sampling yaitu menganggap bahwa sampel yang diambil dapat mewakili populasi. Menurut Fachrul (2007), purposive sampling merupakan teknik pengambilan sampel yang digunakan apabila sampel yang akan diambil mewakili pertimbangan tertentu.

\section{Pengambilan Sampel}

Metode pengambilan sampel larva dilakukan secara manual dengan menarik jaring mini Seine Net berukuran 2 x 1 meter dengan mesh size $1 \mathrm{~mm}$ sejauh 25 meter setiap titiknya. Pengambilan sampel larva ikan dilakukan sebanyak 2 kali penyisiran. Sampling dilakukan secara tegak lurus dan melakukan penyisiran berlawanan dengan arus berdasarkan Gambar 2. Pada saat pasang dilakukan penyisiran ke arah laut, sedangkan pada saat surut dilakukan penyisiran ke arah muara atau daratan. 


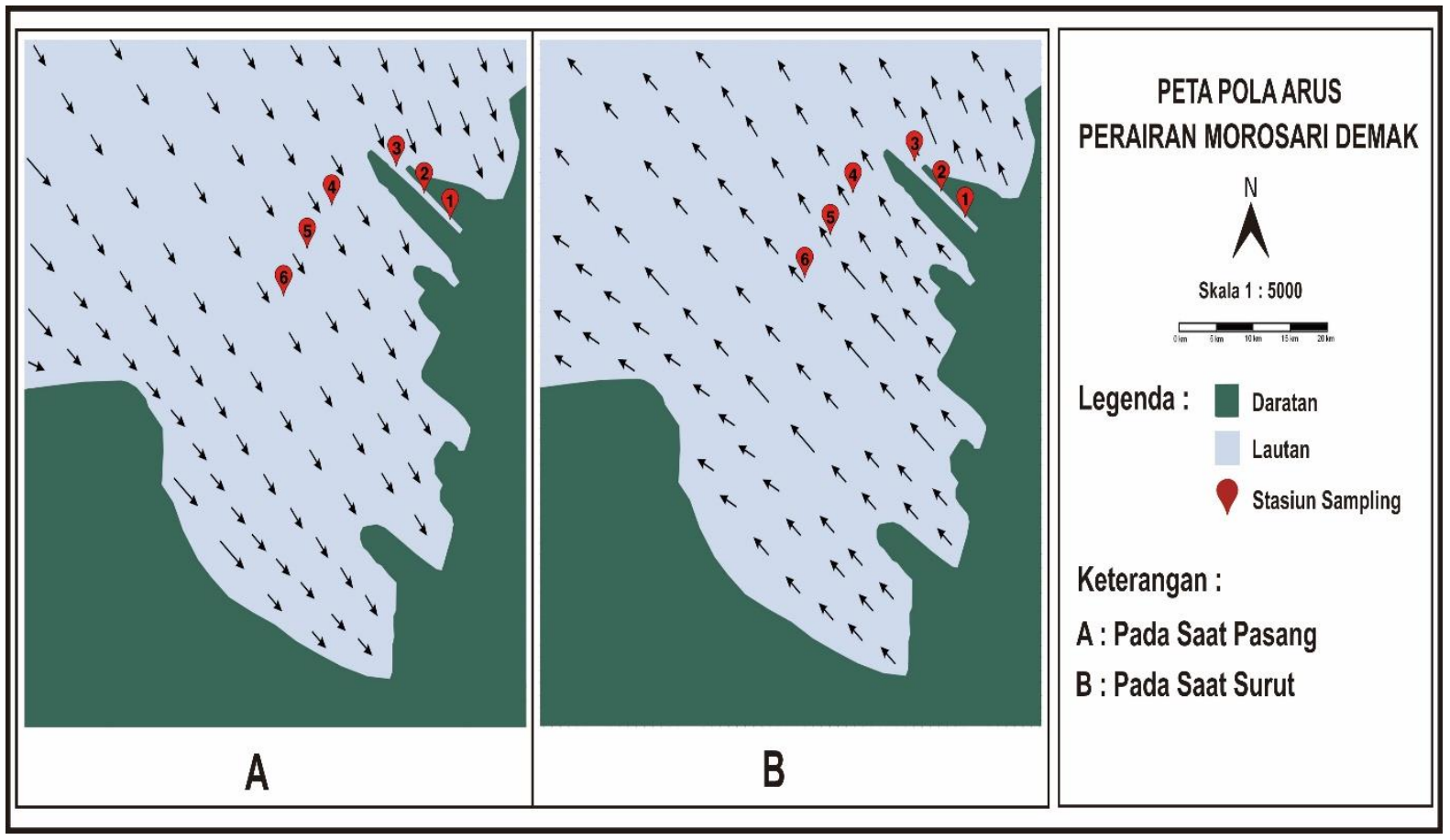

Gambar 2. Peta Pola Arus Pada Saat Surut

\section{Analisis Data}

\section{Independent-Sample $\mathbf{T}$ test}

Uji Independent-Sample T test digunakan untuk menguji signifikansi beda rata-rata dua kelompok, dan juga digunakan untuk menguji pengaruh variabel independen terhadap variabel dependen (Salamun, 2012). Untuk mengetahui perbedaan kelimpahan larva ikan saat pasang dan surut ketentuannya sebagai berikut: Hipotesis:

$\mathrm{H}_{0}=$ Tidak terdapat perbedaan yang signifikan antara kelimpahan larva ikan saat pasang dan surut

$\mathrm{H}_{1} \quad$ = Terdapat perbedaan yang signifikan antara kelimpahan larva ikan saat pasang dan surut Kriteria keputusan:

\section{Kelimpahan Larva Ikan}

a. $\mathrm{H}_{0}$ diterima jika nilai probabilitas $>0,05$

b. $\mathrm{H}_{0}$ ditolak jika nilai probabilitas $<0,05$

Kelimpahan larva ikan didefinisikan sebagai banyaknya larva ikan per satuan volume daerah pengambilan (Taufik, 2012). Dihitung menggunakan rumus sebagai berikut:

Keterangan:

$$
\mathrm{N}=\mathrm{n} / \mathrm{Vtsr}
$$

$\mathrm{N}=$ Kelimpahan larva ikan (ind $\left./ \mathrm{m}^{3}\right)$

$\mathrm{n}=$ Jumlah larva ikan yang didapat (ind)

$\mathrm{Vtsr}=$ Volume air tersaring $(\mathrm{Vtsr}=$ luas jaring $\mathrm{x}$ panjang penarikan $)$

\section{Struktur Komunitas}

Indeks keanekaragaman dapat diartikan sebagai suatu penggambaran secara sistematik yang melukiskan struktur komunitas untuk memudahkan proses analisis informasi-informasi mengenai macam dan jumlah organisme. Semakin banyak jenis yang ditemukan, maka keanekaragaman semakin besar; meskipun nilai ini sangat tergantung dari jumlah individu masing-masing jenis. Semakin banyak dan merata jumlah individu komunitas, maka indeks keanekaragaman juga akan semakin besar. Menurut Odum (1993), untuk perhitungan keanekaragaman digunakan indeks Shannon-Wiener:

$\mathrm{H}^{\prime}=-\sum_{n=1}^{s} p i \ln p i$

Keterangan:

$\mathrm{H}^{\prime}=$ Indeks Keanekaragaman Shannon-Wiener

$\mathrm{pi}=$ perbandingan jumlah individu ke-i dengan jumlah total individu (ni/N)

$\mathrm{ni}=$ jumlah individu suatu jenis

$\mathrm{N}=$ jumlah individu seluruh jenis

Menurut Wilhm \& Dorris (1968) dalam Suwignyo (1976), kriteria indeks keanekaragaman dibagi dalam 3 kategori yaitu: 
$\mathrm{H}^{\prime}<1 \quad$ : Keanekaragaman jenis rendah

$1<\mathrm{H}^{\prime}<3 \quad$ : Keanekaragaman jenis sedang

$\mathrm{H}^{\prime}>3 \quad$ : Keanekaragaman jenis tinggi

Indeks keseragaman adalah komposisi tiap individu pada suatu spesies yang terdapat dalam suatu komunitas. Indeks keseragaman (E) merupakan pendugaan yang baik untuk menentukan dominasi dalam suatu area, apabila satu atau beberapa jenis melimpah dari yang lainnya maka indeks keseragaman akan rendah. Menurut Poole (1974) dalam Supono (2008), keseragaman jenis dapat dibandingkan dengan indeks keseragaman yaitu dengan nilai maksimumnya, menggunakan rumus sebagai berikut:

Keterangan:

$$
\mathrm{e}=\frac{H^{\prime}}{H \max }
$$

$\mathrm{e}=$ Indeks keseragaman

$\mathrm{H}^{\prime}=$ Indeks keanekaragaman Shannon-Wiener

$\mathrm{H} \max =\log _{2} \mathrm{~S}=$ Indeks keanekaragaman maksimum

$\mathrm{s}=$ Jumlah maksimum

Menurut Krebs (1999) indeks keseragaman berkisar 0-1 dengan klasifikasi sebagai berikut:

0,6-1 : Tingkat keseragaman populasi tinggi

$0,4-0,6 \quad$ : Tingkat keseragaman populasi sedang

$0-0,4 \quad$ : Tingkat keseragaman populasi rendah

Indeks dominasi (D) digunakan untuk mengetahui sejauh mana suatu spesies atau genus mendominasi kelompok lain. Dominasi yang cukup besar akan mengarah pada komunitas yang labil maupun tertekan (Odum, 1993). Perhitungan indeks dominansi menggunakan rumus sebagai berikut:

Keterangan:

$$
\mathrm{D}=\sum\left(\frac{n i}{N}\right)^{2}
$$

D = Indeks Dominansi Simpson (0-1,0)

ni $=$ Jumlah individu ke $\mathrm{i}$

$\mathrm{n}=$ Jumlah total individu

Angka D berkisar antara 0,0-1,0 apabila angka D mendekati 0,0 berarti hampir tidak ada individu yang mendominasi dan biasanya diikuti angka e yang besar (mendekati 1); sedangkan apabila angka D mendekati 1 berarti terjadi dominasi spesies tertentu dan dicirikan dengan angka e yang lebih kecil atau mendekati 0 .

\section{Pelaksanaan Penelitian}

Penelitian dilaksanakan pada bulan Juli 2017. Lokasi sampling pada penelitian tersaji pada Gambar 3.

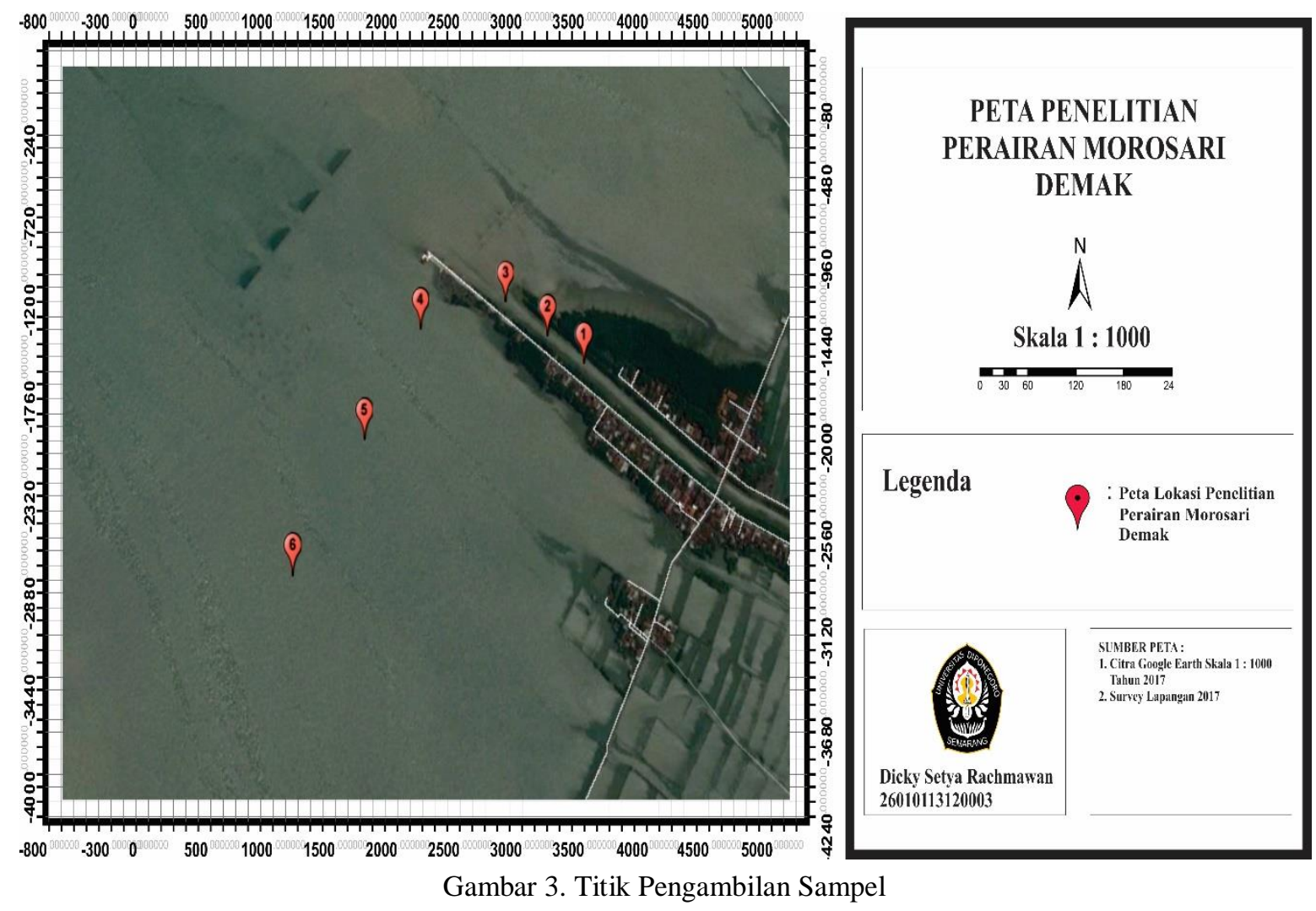

${ }^{\circledR}$ Copyright by Management of Aquatic Resources (MAQUARES) 


\section{HASIL DAN PEMBAHASAN}

\section{Hasil}

Variabel Kualitas Perairan di Lokasi Penelitian

Variabel yang diukur di lokasi penelitian meliputi kecerahan, kedalaman, suhu air, $\mathrm{pH}$, salinitas, kecepatan arus dan pasang surut. Adapun hasil pengukuran dari 6 stasiun penelitian baik pada saat pasang maupun pada saat surut dapat dilihat pada Tabel 1.

Tabel 1. Kisaran Parameter Kualitas Air pada Lokasi Penelitian

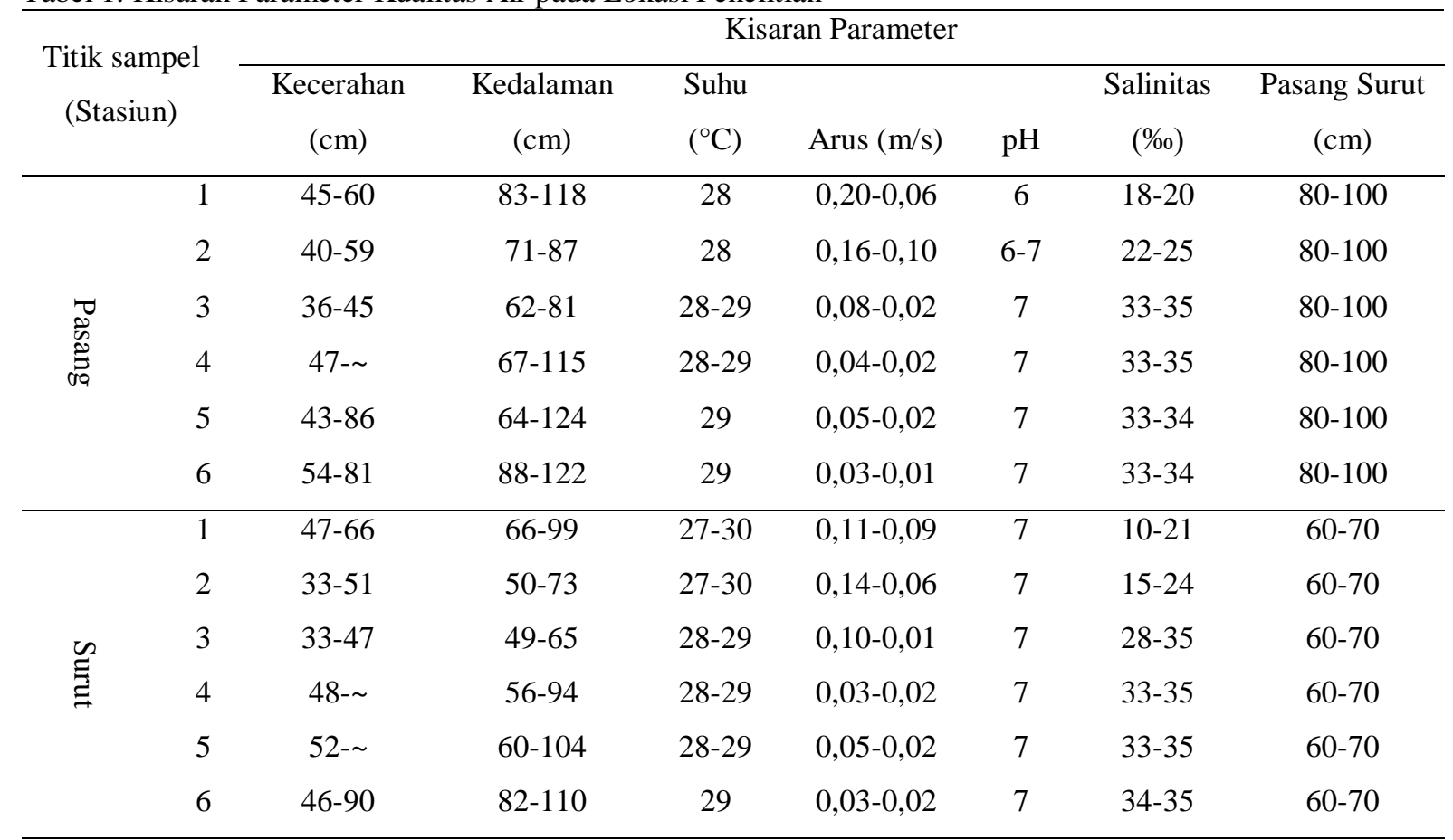

Sumber : Penelitian 2017

Komposisi Larva Ikan

Total Jumlah larva ikan yang berhasil diidentifikasi di kawasan perairan Morosari, Demak sebanyak 1.156 ind $/ 600 \mathrm{~m}^{3}$ yang terdiri dari 8 famili. Berdasarkan titik pengambilan sampel, komposisi larva ikan yang tertangkap secara keseluruhan tersaji dalam Tabel 2.

Tabel 2. Komposisi Jenis dan Jumlah Larva Ikan $\left(\right.$ ind $/ 600 \mathrm{~m}^{3}$ ) yang Tertangkap di Semua Stasiun Pengambilan Sampel

\begin{tabular}{|c|c|c|c|c|c|c|c|c|c|c|c|c|c|c|}
\hline \multirow{3}{*}{ No } & \multirow{3}{*}{ Famili } & \multicolumn{12}{|c|}{ Sampling di Stasiun } & \multirow{3}{*}{$\begin{array}{c}\sum \\
\text { (ekor) }\end{array}$} \\
\hline & & \multicolumn{6}{|c|}{ Keadaan Pasang } & \multicolumn{6}{|c|}{ Keadaan Surut } & \\
\hline & & 1 & 2 & 3 & 4 & 5 & 6 & 1 & 2 & 3 & 4 & 5 & 6 & \\
\hline 1 & Ambassidae & 0 & 0 & 11 & 103 & 77 & 89 & 0 & 0 & 13 & 98 & 90 & 70 & 551 \\
\hline 2 & Belonidae & 7 & 10 & 0 & 0 & 0 & 0 & 0 & 16 & 0 & 0 & 0 & 0 & 33 \\
\hline 3 & Engraulidae & 0 & 0 & 14 & 7 & 24 & 22 & 0 & 0 & 17 & 9 & 9 & 16 & 118 \\
\hline 4 & Gobiidae & 1 & 2 & 0 & 0 & 0 & 0 & 3 & 2 & 0 & 0 & 0 & 0 & 8 \\
\hline 5 & Lutjanidae & 0 & 0 & 0 & 3 & 2 & 0 & 0 & 0 & 0 & 0 & 2 & 0 & 7 \\
\hline 6 & Mugilidae & 20 & 29 & 3 & 29 & 0 & 2 & 6 & 9 & 0 & 10 & 10 & 12 & 130 \\
\hline 7 & Nemipteridae & 0 & 0 & 34 & 4 & 28 & 41 & 0 & 0 & 30 & 23 & 22 & 24 & 206 \\
\hline \multirow[t]{2}{*}{8} & Oryziatidae & 29 & 22 & 0 & 0 & 0 & 0 & 30 & 22 & 0 & 0 & 0 & 0 & 103 \\
\hline & & 57 & 63 & 62 & 146 & 131 & 154 & 39 & 49 & 60 & 140 & 133 & 122 & 1156 \\
\hline
\end{tabular}

Sumber: Penelitian 2017 
Tabel 2. memperlihatkan bahwa famili Oryziatidae, Belonidae dan Gobiidae hanya ditemukan pada stasiun 1 dan 2, diikuti famili Ambassidae, Engraulidae, Nemipteridae dan Lutjanidae pada stasiun 3-6, adapun famili Mugilidae ditemukan di semua stasiun. Jumlah spesies larva ikan berbeda antara lokasi satu dengan lokasi lainnya, diperkirakan larva ikan memiliki preferensi habitat yang berbeda pula. Sementara itu komposisi larva ikan yang tertangkap secara keseluruhan berdasarkan pasang surut tersaji pada Tabel 3.

Tabel 3. Komposisi Jenis dan Jumlah Individu Larva Ikan yang Tertangkap

\begin{tabular}{rlccr}
\hline \multirow{2}{*}{ No } & \multirow{2}{*}{ Famili } & \multicolumn{2}{c}{ Jumlah Individu } & \multirow{2}{*}{$\sum$ (ekor) } \\
\cline { 3 - 5 } & & Keadaan Pasang & Keadaan Surut & 551 \\
2 & Ambassidae & 280 & 271 & 33 \\
3 & Belonidae & 17 & 16 & 118 \\
4 & Engraulidae & 67 & 51 & 8 \\
5 & Lobiidae & 3 & 5 & 7 \\
6 & Mugilidanidae & 5 & 2 & 130 \\
7 & Nemipteridae & 83 & 47 & 206 \\
8 & Oryziatidae & 107 & 99 & 103 \\
\hline & $\sum$ & 613 & 52 & 1156 \\
\hline
\end{tabular}

Sumber : Penelitian 2017

Histogram jumlah larva ikan yang didapatkan berdasarkan pasang surut selama penelitian tersaji pada Gambar 4.

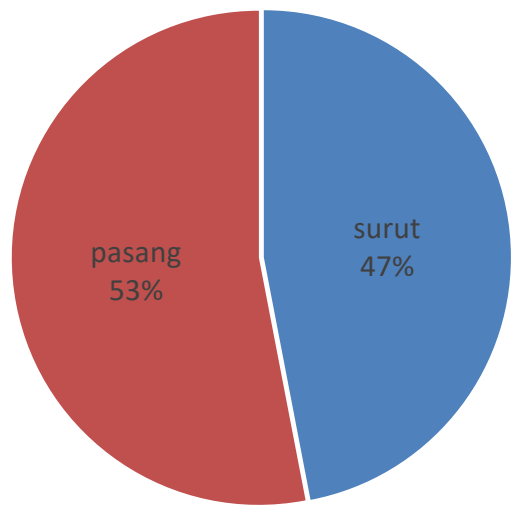

Gambar 4. Jumlah Larva Ikan yang Didapatkan Saat Pasang dan Surut di Dukuh Morosari Desa Bedono, Kabupaten Demak.

\section{Kelimpahan Larva Ikan}

Hasil perhitungan kelimpahan rata-rata (ind $/ \mathrm{m}^{3}$ ) larva ikan di kawasan perairan Morosari Demak tersaji dalam Tabel 4.

Tabel 4. Rata-rata Kelimpahan Larva Ikan (ind $/ \mathrm{m}^{3}$ ) pada 6 Titik pada Saat Pasang dan Surut

\begin{tabular}{cccc}
\hline \multirow{6}{*}{ Titik Sampel } & & $\mathrm{n}($ ind $) / 600 \mathrm{~m}^{3}$ & $\mathrm{~N}\left(\mathrm{ind} / \mathrm{m}^{3}\right)$ \\
\hline \multirow{4}{*}{ Pasang } & 1 & 57 & 0,57 \\
& 2 & 63 & 0,63 \\
& 3 & 62 & 0,62 \\
& 4 & 146 & 1,46 \\
& 5 & 131 & 1,31 \\
Surut & 6 & 154 & 1,54 \\
& 1 & 39 & 0,39 \\
& 2 & 49 & 0,49 \\
& 3 & 60 & 0,60 \\
& 4 & 140 & 1,40 \\
& 5 & 133 & 1,33 \\
& 6 & 122 & 1,22 \\
\hline
\end{tabular}

${ }^{\circ}$ Copyright by Management of Aquatic Resources (MAQUARES) 
Sumber : Penelitian 2017

Kelimpahan rata-rata di enam titik penelitian pada saat pasang dan surut menunjukkan bahwa titik 6 pada saat pasang memiliki kelimpahan yang paling tinggi $\left(154 \mathrm{ind} / 600 \mathrm{~m}^{3}\right)$ dan yang paling rendah adalah titik 1 pada saat pasang maupun surut $\left(39 \mathrm{ind} / 600 \mathrm{~m}^{3}\right.$ dan $\left.57 \mathrm{ind} / 600 \mathrm{~m}^{3}\right)$. Histogram kelimpahan larva ikan dapat dilihat pada Gambar 5.

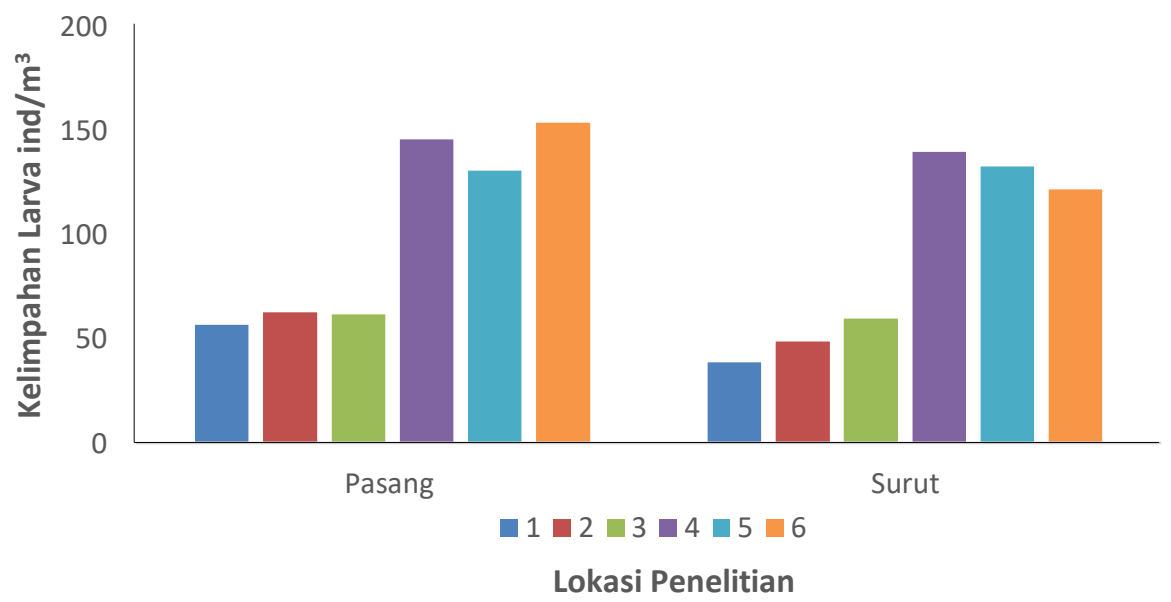

Gambar 5. Kelimpahan Larva Ikan yang Didapatkan Saat Pasang dan Surut di Dukuh Morosari Desa Bedono, Kabupaten Demak.

\section{Perbedaan Kelimpahan Larva Ikan Saat Pasang dan Surut}

Hasil uji Independent-Sample T test dengan membandingkan angka kelimpahan larva ikan saat pasang dan surut berdasarkan setiap stasiun dan setiap pengulangan dapat dilihat pada Tabel 5.

Tabel 5. Kelimpahan Larva Ikan Saat Pasang dan Surut Berdasarkan Setiap Stasiun dan Setiap Pengulangan

Analisa Uji Independent-Sample T test Asymp. Sig.

Setiap Stasiun

0,946

Setiap Pengulangan

0,778

Sumber : Hasil olahan dari SPSS

Berdasarkan Tabel 5. angka kelimpahan larva ikan saat pasang dan surut setiap stasiun (Sig.) 0,946 dan pada setiap pengulangan (Sig.) 0,778. Karena probabilitas (Sig.) 0,946 dan (Sig.) 0,778 maka $\mathrm{H}_{0}$ diterima. Artinya tidak terdapat perbedaan yang signifikan antara kelimpahan larva ikan saat pasang dan surut pada setiap stasiun maupun setiap pengulangan.

\section{Struktur Komunitas Larva Ikan}

Struktur komunitas larva ikan yang dihitung meliputi indeks keanekaragaman (H'), indeks keseragaman (E), dan indeks dominasi (D). Adapun angka indeks keanekaragaman, keseragaman, dan dominasi di Kawasan Perairan Morosari tersaji dalam Tabel 6.

Tabel 6. Struktur Komunitas Larva Ikan di Kawasan Perairan Morosari, Demak

\begin{tabular}{ccccc}
\hline Titik Sampel & & Keanekaragaman & Keseragaman & Dominasi \\
\hline \multirow{6}{*}{ Pasang } & 1 & 1,0398 & 0,7501 & 0,3974 \\
& 2 & 1,1262 & 0,8124 & 0,3600 \\
& 3 & 1,1188 & 0,8070 & 0,3855 \\
& 4 & 0,8912 & 0,5338 & 0,5406 \\
& 5 & 1,0169 & 0,7335 & 0,4250 \\
\multirow{2}{*}{ Surut } & 6 & 1,0036 & 0,7240 & 0,4255 \\
& 1 & 0,6871 & 0,6254 & 0,6213 \\
& 2 & 1,1668 & 0,8417 & 0,3436 \\
& 3 & 1,0353 & 0,9424 & 0,3772
\end{tabular}

${ }^{\circledR}$ Copyright by Management of Aquatic Resources (MAQUARES) 


$\begin{array}{llll}4 & 0,9113 & 0,6574 & 0,5262 \\ 5 & 0,9387 & 0,6771 & 0,4955 \\ 6 & 1,1331 & 0,8173 & 0,3948\end{array}$

Sumber : Penelitian 2017

Pembahasan

Komposisi dan Kelimpahan Larva Ikan

Pada saat sampling, larva ikan sering kali berkelompok dan berenang lambat di permukaan sehingga mudah ditangkap menggunakan mini Seine Net. Menurut Subiyanto et al. (2008), berdasarkan cara hidupnya yang masih digolongkan planktonik, larva ikan bergerak secara pasif, mengikuti arus air perairan di sekitarnya. Perkembangan alat gerak yang belum sempurna, terutama pada tahap yolk-sac dan pre-flexion diduga kuat menyebabkan larva ikan terdistribusi ke wilayah lain atau ke perairan yang lebih dangkal seperti daerah mangrove dan pantai. Nybaken (1992) menyatakan bahwa adanya keterkaitan ekosistem antara mangrove dengan ekosistem lainnya ditunjukkan dengan adanya migrasi ikan menuju mangrove. Migrasi ini dilakukan dengan tiga alasan, yaitu pertama migrasi yang dilakukan ikan dari satu tempat ke tempat yang lain sesuai dengan tahapan atau daur hidupnya. Kedua yaitu migrasi yang dilakukan pada waktu tertentu setiap tahun. Ketiga adalah migrasi yang dilakukan setiap hari.

Famili Ambassidae memiliki jumlah tangkapan yang paling tinggi dan merupakan jenis yang mendominasi di stasiun 4, 5 dan 6, sehingga diduga pantai merupakan daerah asuhan yang cocok bagi famili Ambassidae. Redjeki et al. (2013), menyatakan bahwa famili Ambassidae memiliki distribusi komposisi terluas di daerah pantai termasuk estuaria. Ikan ini hidup pada kisaran salinitas yang luas, karena dapat hidup di air payau dan laut yang berasosiasi dengan terumbu. Jenis ikan ini sering terdapat di estuari dan sungai, bersifat katadromus, biasanya membentuk kelompok yang besar di daerah dengan dasar pasir atau lumpur.

Famili Gobiidae yaitu ikan gelodok atau biasa disebut ikan beloso juga tertangkap di kawasan perairan Morosari Demak. Secara umum famili Gobiidae ditemukan pada daerah muara sungai dan daerah hutan mangrove yang kaya kandungan bahan organik, sebagai feeding habit bagi famili Gobiidae. Hal ini didukung oleh pendapat Subiyanto et al. (2008), yang menyatakan bahwa famili Gobiidae memiliki kemampuan adaptasi yang baik terhadap lingkungan mangrove dan biasanya dominan tertangkap di perairan tersebut.

Dalam penelitian ini famili Mugilidae ditemukan di semua wilayah pada lokasi penelitian. Redjeki et al. (2013), menyatakan bahwa famili Mugilidae termasuk dalam kelompok ikan yang mempunyai kemampuan adaptasi cukup baik, sehingga larva ikan ini dapat ditemukan hampir di semua perairan; ikan belanak merupakan ikan yang berasosiasi dengan hutan mangrove selama periode larva dan juvenil, tetapi pada saat dewasa cenderung menggerombol di sepanjang pantai yang berdekatan dengan hutan mangrove.

Pengaruh Pasang Surut Terhadap Kelimpahan Larva Ikan

Berdasarkan penelitian di perairan Morosari Demak tidak terdapat perbedaan kelimpahan larva ikan yang signifikan pada saat pasang dan surut. Hal ini karena air pasang membantu dalam imigrasi atau distribusi larva ikan di laut. Arus dan pasang surut membawa dan menyebarkan larva yang masih bersifat planktonik. Menurut Prianto et al. (2013), bahwa faktor hidrografi di perairan pantai atau daerah asuhan berpengaruh sebagai stimuli tingkah laku imigrasi larva ikan di antaranya adalah aliran pasang surut (tidal flux) termasuk di dalamnya kecepatan arus, salinitas (terutama untuk perairan estuari), dan juga pengaruh siklus bulan. Menurut Subiyanto $e t$ al. (2009), perbedaan kelimpahan larva ikan setiap lokasi dapat disebabkan oleh perbedaan kedalaman air akibat tinggi pasang yang berbeda. Hal ini berpengaruh pada arus yang membawa atau memindahkan larva ikan dan selanjutnya akan mempengaruhi kelimpahan.

Pasang surut merupakan faktor lingkungan yang paling penting mempengaruhi kehidupan organisme laut, terutama ichthyoplankton. Pasang surut menimbulkan perputaran air, sehingga terjadi transpor vertikal dari ichthyoplankton. Relatif kecilnya perputaran air oleh pasang surut menyebabkan ichthyoplankton ditemukan pada kedalaman yang lebih dalam. Transpor vertikal ke atas dari ichthyoplankton berhubungan erat dengan kecepatan arus pasang surut, terutama pada pasang naik (Boehlert et al., 1985). Menurut Olii (2003), jumlah nener bandeng banyak dijumpai pada saat air pasang tinggi daripada air surut, juga banyak terdapat pada bulan purnama dan bulan gelap. Hal ini diperkuat juga oleh Mantiri (1995) yang menjumpai banyak larva dan juvenil ikan pada saat air pasang.

Perbedaan jumlah kelimpahan larva saat pasang dan surut karena ketika air pasang larva ikan banyak yang terbawa ke estuarin oleh arus pasang dan menghindari arus surut dengan bertahan pada sisi perairan estuarin, karena pada daerah estuarin mereka menemukan tempat yang sesuai untuk tumbuh dan berkembang. Larva dipindahkan oleh arus mengalir menuju mulut estuari selama pasang, dan larva ikan yang terdistribusi ke mulut estuari adalah larva dan ikan muda (Subiyanto et al., 2009).

\section{Struktur Komunitas Larva Ikan}

Indeks keanekaragaman $\left(\mathrm{H}^{\prime}\right)$, keseragaman $(\mathrm{E})$ dan dominasi (D) digunakan untuk mengetahui pengaruh kualitas lingkungan terhadap komunitas. Pengaruh kualitas lingkungan terhadap kelimpahan individu selalu berbeda-beda tergantung pada jenis spesies, karena setiap ikan memiliki adaptasi dan toleransi yang berbeda terhadap habitatnya. Kondisi lingkungan suatu perairan dikatakan baik bila diperoleh nilai indeks keanekaragaman (H') dan keseragaman (E) yang tinggi, serta indeks dominansi (D) yang rendah (Hukom, 1999).

\footnotetext{
${ }^{\oplus}$ Copyright by Management of Aquatic Resources (MAQUARES)
} 
Indeks keanekaragaman (H') yang diperoleh berdasarkan perhitungan pada setiap titik menunjukkan angka yang cukup beragam. Kisaran nilai keanekaragaman ( $\mathrm{H}^{\prime}$ ) pada lokasi penelitian yaitu 0,68 - 1,16 (Tabel 7) termasuk dalam kriteria angka keanekaragaman $1<\mathrm{H}^{\prime}<3$ sehingga dapat ditarik kesimpulan bahwa nilai H' larva ikan yang tertangkap selama kegiatan penelitian dapat digolongkan ke dalam keanekaragaman jenis sedang. Menurut Wilhm dan Dorris (1968) dalam Suwignyo (1976), indeks keanekaragaman akan mencapai maksimum bila kelimpahan individu per jenis menyebar secara merata. Hal ini berarti dalam suatu komunitas, jumlah individu setiap spesiesnya relatif sama atau seragam sehingga tidak ada spesies tertentu yang mendominasi.

Indeks keseragaman (E) digunakan untuk mengetahui berapa besar kesamaan penyebaran jumlah individu setiap genus pada tingkat komunitas ditiap lokasi penelitian. Hasil analisis menunjukkan bahwa nilai indeks keseragaman di kawasan perairan Morosari Demak berkisar antara 0,53 - 0,94 (Tabel 7) termasuk dalam kriteria angka mendekati 1, hal ini berarti tingkat produktivitas tinggi. Menurut Pirzan dan Pong-Masak (2008), semakin besar nilai keseragaman dapat dikatakan merata atau jumlah individu dalam spesies relatif sama, sedangkan keseragaman yang bernilai kecil menggambarkan keseragaman antar spesies di dalam komunitas rendah, yang berarti kekayaan individu yang dimiliki masing-masing spesies sangat jauh berbeda.

Indeks dominasi (D) digunakan untuk mengetahui ada atau tidaknya spesies tertentu yang mendominasi suatu ekosistem. Nilai indeks dominasi larva ikan yang ada di kawasan perairan Morosari Demak berkisar antara 0,34 0,62 (Tabel 7) termasuk dalam kriteria angka mendekati 1, angka ini menunjukkan bahwa pada lokasi penelitian terdapat jenis yang mendominasi yaitu larva famili Ambassidae dan Oryziatidae. Menurut Dhahiyat et al. (2009), bila dalam suatu struktur komunitas biota yang diamati terdapat spesies yang mendominasi, maka hal ini menunjukkan bahwa komunitas berada dalam keadaan labil atau sedang terjadi tekanan ekologis.

\section{KESIMPULAN}

Kesimpulan yang dapat diambil dari penelitian ini adalah sebagai berikut:

1. Jumlah larva ikan yang tertangkap selama penelitian secara keseluruhan berjumlah $1.156 \mathrm{ind} / 600 \mathrm{~m}^{3}$. Larva ikan yang teridentifikasi terdiri dari 8 famili yakni Ambassidae, Belonidae, Engraulidae, Gobiidae, Lutjanidae, Mugilidae, Nemipteridae, dan Oryziatidae. Larva famili Ambassidae merupakan larva yang paling banyak tertangkap dengan jumlah 551 ind $/ 600 \mathrm{~m}^{3}$. Larva yang tertangkap dengan jumlah paling sedikit ialah famili Lutjanidae dengan jumlah 7 ind $/ 600 \mathrm{~m}^{3}$.

2. Jumlah larva ikan pada saat pasang $613 \mathrm{ind} / 600 \mathrm{~m}^{3}$ dan pada saat surut $543 \mathrm{ind} / 600 \mathrm{~m}^{3}$. Tidak terdapat perbedaan yang signifikan antara kelimpahan larva ikan saat pasang dan surut pada setiap stasiun maupun setiap pengulangan.

\section{UCAPAN TERIMAKASIH}

Ucapan terimakasih ditujukan kepada Ir. Anhar Solichin, M.Si dan Wiwiet Teguh., S.Pi, M.Si yang telah memberikan saran dan kritik yang sangat bermanfaat bagi penulis. Kepada semua pihak yang telah membantu sehingga penulis dapat menyelesaikan artikel ini.

\section{DAFTAR PUSTAKA}

Boehlert, G.W., D.M. Gadomski, dan B. C. Mundy. 1993. Vertical Distribution of Ichthyoplankton of the Oregon Coast in Spring and Summer Months. Fish Bull. 83 .4:611-621

Dhahiyat, Y., Sinuhaji, dan H. Hamdani. 2009. Struktur Komunitas Ikan Karang di Daerah Transplantasi Karang Pulau Pari Kepulauan Seribu [Community Structure of Coral Reef Fish in the Coral Transplantation Area Pulau Pari Kepulauan Seribu]. Jurnal Ikhtiologi Indonesia. III (2):87-94.

Djou, J.A.G. 2013. Pengembangan 24 Destinasi Wisata Bahari Kabupaten Ende. Fakultas Ekonomi Universitas Flores. Vol (3):1-116

Fachrul, M. F. 2007. Metode Sampling Bioekologi. Bumi Aksara. Jakarta. 198 hlm.

Hukom, F. D. 1999. Ekostruktur dan distribusi spasial ikan karang (famili Labridae) di perairan Teluk Ambon. Pros. Lok. Pengelolaan dan Iptek Terumbu Karang Indonesia. Jakarta. 134-145.

Krebs, C. J. 1999. Ecological Method. An Imprint of Addison Wesley Longman, Inc, Columbia. $636 \mathrm{hlm}$.

Mantiri R.O.S.E. 1995. Ichthyoplanktonologi. Manado: Pasca Sarjana. Unsrat.

Nazir, M. 1999. Metode Penelitian. Ghalia Indonesia, Jakarta. 622 hlm.

Nybakken, J.W. 1992. Biologi Laut. Suatu Pendekatan Ekologis. Gramedia Pustaka Utama. 459 hlm.

Odum, P. E. 1993. Dasar-dasar Ekologi: Alih Bahasa Tjahjono Samingan. Edisi Ketiga Universitas Gajah Mada. Yogyakarta. $697 \mathrm{hlm}$.

Olii, A.H. 2003. Kajian Faktor Fisik Yang Mempengaruhi Distribusi Ichthyoplankton (Awal Daur Hidup Ikan). Progam Pascasarjana Institut Pertanian Bogor. 197-265.

Pirzan, A. M. dan P. R. Pong-Masak. 2008. Hubungan Keragaman Fitoplankton dengan Kualitas Air di Pulau Baulung Kabupaten Takalar Sulawesi Selatan. Biodiversitas. Maros: Balai Riset Perikanan Budidaya Air Payau. IX (3):217-221. 
Prianto, E., S. Nurdawaty dan M. M. Kamal. 2013. Distribusi, Kelimpahan dan Variasi Ukuran Larva Ikan di Estuari Sungai Musi. Jurnal Bawal. Vol V(2):73-79.

Rejeki, S., Irwani., F.M. Hisyam. 2013. Struktur komunitas ikan pada ekosistem mangrove di Desa Bedono, Sayung, Demak. Jurnal Buletin Oseanografi Marin, $2: 78-86$

Rohman, F. 2016. Partisipasi Masyarakat Dalam Pengembangan Kawasan Ekowisata di Desa Bedono Kecamatan Sayung, Kabupaten Demak. Univestitas Diponegoro. Semarang

Romimohtarto, K dan S. Juwana. 2004. Meroplankton Laut. Djambatan. Jakarta.

Salamun, Abdullah. 2012. Pengaruh Metode Mengajar Praktik Padat dan Distribusi Terhadap Hasil Belajar Permainan Bola Voli. Repository.Upi.Edu. Universitas Pendidikan Indonesia

Subiyanto, Ruswahyuni, dan D. G. Cahyono. 2008. Komposisi dan Distribusi Larva Ikan Pelagis di Estuaria Pelawangan Timur Segara Anakan Cilacap. Jurnal Saintek Perikanan. IV (1):62-68.

Subiyanto, N. Widyorini dan Iswahyuni. 2009. Pengaruh Pasang Surut terhadap Rekruitmen Larva Ikan di Pelawangan Timur Segara Anakan Cilacap. Jurnal Saintek Perikanan. V (1):44-48.

Supono. 2008. Analisis Diatom Epipelic Sebagai Indikator Kualitas Lingkungan Tambak Untuk Budidaya Udang. Program Studi Magister Manajemen Sumberdaya Pantai, Program Pascasarjana Universitas Diponegoro. Semarang

Suwignyo, P. 1976. Metode dan Teknik Penelitian Bidang Biologi Perairan. Institut Pertanian Bogor. $53 \mathrm{hlm}$.

Taufik, Muhammad. 2012. Distribusi dan Kelimpahan Larva Ikan di Perairan Laguna Pulau Pari dan Sekitarnya. Program Pascasarjana Institut Pertanian Bogor. 